\title{
Competitiveness study in tourist corridors: the Brazil-Paraguay-Argentine-Chile Bioceanic Route case
}

\author{
Estudo da competitividade em corredores turísticos: o caso da Rota Bioceânica \\ Brasil-Paraguai-Argentina-Chile
}
Estudio de competitividad en corredores turísticos: el caso de la Ruta Bioceánica Brasil-Paraguay-Argentina-Chile

\author{
Erick Wilke ${ }^{1}$ \\ Debora Fittipaldi Gonçalves² \\ Thiago Andrade Asato ${ }^{3}$
}

Received on 30 June 2021; revised and approved on 28 Sept. 2021; accepted on 13 Oct. 2021

DOI: http://dx.doi.org/10.20435/inter.v22i4.3425

\begin{abstract}
The present article deals with a study of competitiveness in the Bioceanic Route, which is made up of the Brazil, Paraguay, Argentine, and Chile countries. The general objective of this research concerns the competitiveness of tourist corridors with a focus on the countries mentioned above. As research methodology, the present investigation had a qualitative and descriptive nature. The study has a deductive approach based on bibliographical and exploratory research, in face of theoretical description and characterization, as well as documentary research, by the access to files and documents during the investigation; and moreover, for carrying out the field research stage, the criteria selected were the main destinations crossing the Bioceanic Route, for observation and data collection, and local authorities were interviewed. The itinerary considered was from Campo Grande (state of Mato Grosso do Sul, Brazil), Paraguay, and Argentine to ports in Northern Chile. The criteria for analyzing the destinations were as follows: attractiveness, tourist information, transport, general infrastructure, quality of services, accessibility, hospitality, trade relations, destination management, conditional situations, and tourists' perception. Results reveal nonconformity between the main cities in the corridor, such as Campo Grande, Salta, San Pedro de Atacama, and Iquique relative to all the elements analyzed, in relation to the other cities along the route.
\end{abstract}

Keywords: tourism; competitiveness; tourist destinations; Bioceanic Corridor.

Resumo: O presente artigo versa sobre um estudo de competitividade na Rota Bioceânica, que é composta pelos países Brasil-Paraguai-Argentina-Chile. O objetivo geral desta pesquisa versa sobre competitividade de corredores turísticos com foco nos países acima citados. Como metodologia de pesquisa, a presente investigação teve natureza qualitativa e descritiva. O presente estudo apresenta o método dedutivo embasado em pesquisas bibliográfica e exploratória, em face da descrição e da caracterização teórica assim como a pesquisa documental, pelo acesso a arquivos e documentos durante a investigação, como também, para a realização da etapa de pesquisa de campo como critério selecionado foram constituído pelos destinos principais que perpassam a Rota Bioceânica para a observação e a coleta de dados, também foram realizadas entrevistas com autoridades locais. Considerou-o itinerário desde Campo Grande (Estado de Mato Grosso do Sul, Brasil), Paraguai, Argentina até os Portos do Norte do Chile. Os critérios para análise dos destinos foram os seguintes: atratividade, informação turística, transporte, infraestrutura geral, qualidade dos serviços, acessibilidade, hospitalidade, relações comerciais, gestão do destino, situações condicionais e percepção dos turistas. Os resultados revelam uma inconformidade entre as principais cidades do corredor como Campo Grande, Salta, San Pedro de Atacama e Iquique frente a todos os elementos analisados, em relação às demais cidades do percurso.

Palavras-chaves: turismo; competitividade; destinos turísticos; Corredor Bioceânico.

Resumen: Este artículo trata de un estudio de competitividad en la Ruta Bioceánica, que está conformada por los países Brasil-Paraguay-Argentina-Chile. El objetivo general de esta investigación es sobre la competitividad de los corredores turísticos con un enfoque en los países mencionados anteriormente. Como metodología de investigación, la presente investigación tuvo un carácter cualitativo y descriptivo. Este estudio presenta el método deductivo basado en la investigación bibliográfica y exploratoria, frente a la descripción y

\footnotetext{
${ }^{1}$ Federal University of Mato Grosso do Sul (UFMS), Campo Grande, Mato Grosso do Sul, Brasil.

2 State University of Mato Grosso do Sul (UEMS), Campo Grande, Mato Grosso do Sul, Brasil.

${ }^{3}$ Dom Bosco Catholic University (UCDB), Campo Grande, Mato Grosso do Sul, Brasil.
} 


\begin{abstract}
caracterización teórica, así como la investigación documental, mediante el acceso a archivos y documentos durante la investigación, así como para la realización de la etapa de investigación de campo según los criterios seleccionados. constituida por los principales destinos que atraviesan la Ruta Bioceánica para la observación y recolección de datos, también se realizaron entrevistas con las autoridades locales. Lo consideró un itinerario desde Campo Grande (Estado de Mato Grosso do Sul, Brasil), Paraguay, Argentina hasta los puertos del norte de Chile. Los criterios para analizar los destinos fueron los siguientes: atractivo, información turística, transporte, infraestructura general, calidad de los servicios, accesibilidad, hospitalidad, relaciones comerciales, gestión del destino, situaciones condicionales y percepción de los turistas. Los resultados revelan una disconformidad entre las principales ciudades del corredor como Campo Grande, Salta, San Pedro de Atacama e Iquique en relación a todos los elementos analizados en relación al resto de ciudades de la ruta. Palabras clave: turismo; competitividad; destinos turísticos; Corredor Bioceánico.
\end{abstract}

\title{
1 INTRODUCTION
}

The opening of an integration route between South-American countries comprised of Brazil, Paraguay, Argentine, and Chile should pave the way for tourism in large part of this stretch, in course of construction, mainly in Paraguayan territory, which in the route designed for this specific stretch, lacked paving or any other infrastructure.

The construction of a binational bridge between the municipalities of Porto Murtinho, in Brazil, and Carmelo Peralta, in Paraguay, funded almost wholly by Itaipu Binacional, was decisive to drive the process legitimating this new route.

The objective of this study is to investigate competitiveness perspectives in tourist corridors, considering the new itinerary of the Brazil-Paraguay-Argentine-Chile Bioceanic Route. The present investigation is qualitative and descriptive. The study has a deductive approach based on bibliographical and exploratory research, in face of theoretical description and characterization, along with documentary research, by the access to files and documents during the investigation, as well as field research, for observation and data collection.

\section{COMPETITIVENESS OF TOURIST DESTINATIONS}

The fundaments forming the basis of concepts of competitiveness of tourist destinations suggest an extensive capacity of management, and alignment between destination and demand, where organizations and companies have a relevant role in the production aspects and resource allocation, forming a set of products, services, and attractions of high value for consumers, and providing favorable competitive position relative to competing destinations so the general result be the well-being of residents.

Researchers in tourism, especially from the nineties, began to consider how competitiveness in tourist destinations should be understood and measured (RITCHIE; CROUCH, 1993). Since then, an increasing set of researchers has sought to develop a theoretical and conceptual base to approach this problem (DWYER; KIM, 2003; CROUCH, 2011). In this direction, several studies have contributed to the identification of factors associated with competitiveness in tourist destinations (CROUCH; RITCHIE, 1999; RITCHIE; CROUCH, 2000; 2003; DWYER; KIM, 2003; HEATH, 2003; ENRIGHT; NEWTON, 2004; RODRÍGUEZ-DÍAS; ESPINO-RODRÍGUEZ, 2008; CROES, 2011; CROUCH, 2011; ZHANG et al., 2011). Among these studies, some stand out in the academic scenario.

These studies have sought to explain what makes a tourist destination highly competitive relative to competing destinations and that is carried out through the identification of a wide 
set of factors or determinants of competitiveness. These factors represent variables that are grouped into several dimensions associated both with the tourist destination, such as local tourism management, and the environment surrounding it, such as macroeconomic indicators.

In each model it is possible to observe an attempt to identify a set of inter-related factors that come closest to explaining the competitiveness of tourist destinations. Following this premise, studies and models emerged with varied perspectives, an increasing number of factors and little consensus. This can be explained by the fact that competitiveness is an admittedly multifaceted, multidimensional, and relative concept (DWYER et al., 2012; MIKI; GÂNDARA; MUÑOZ, 2012).

One of the studies of greatest relevance in the academic research scenario aimed at competitiveness in tourism was presented by Dwyer and Kim (2003). For the authors, the understanding of competitiveness represents a complex challenge, for this is a multidimensional phenomenon. The model comprises the category Resources, subdivided into natural and historicalcultural resources, created resources, and supporting resources; Destination Management, both governmental and business; Situational Conditions, and Demand. For each category at least three indicators were established, in a total of 81 competitiveness indicators in tourism. In a subsequent study (DWYER et al., 2004), those indicators were used as a reference source to list eleven principal components. The relevance of the study lies in the authors' concern with explaining the relationship ties between determining factors of competitiveness (MAZANEC; WOBER; ZINS, 2007).

Figure 1 - Competitiveness model of tourist destinations

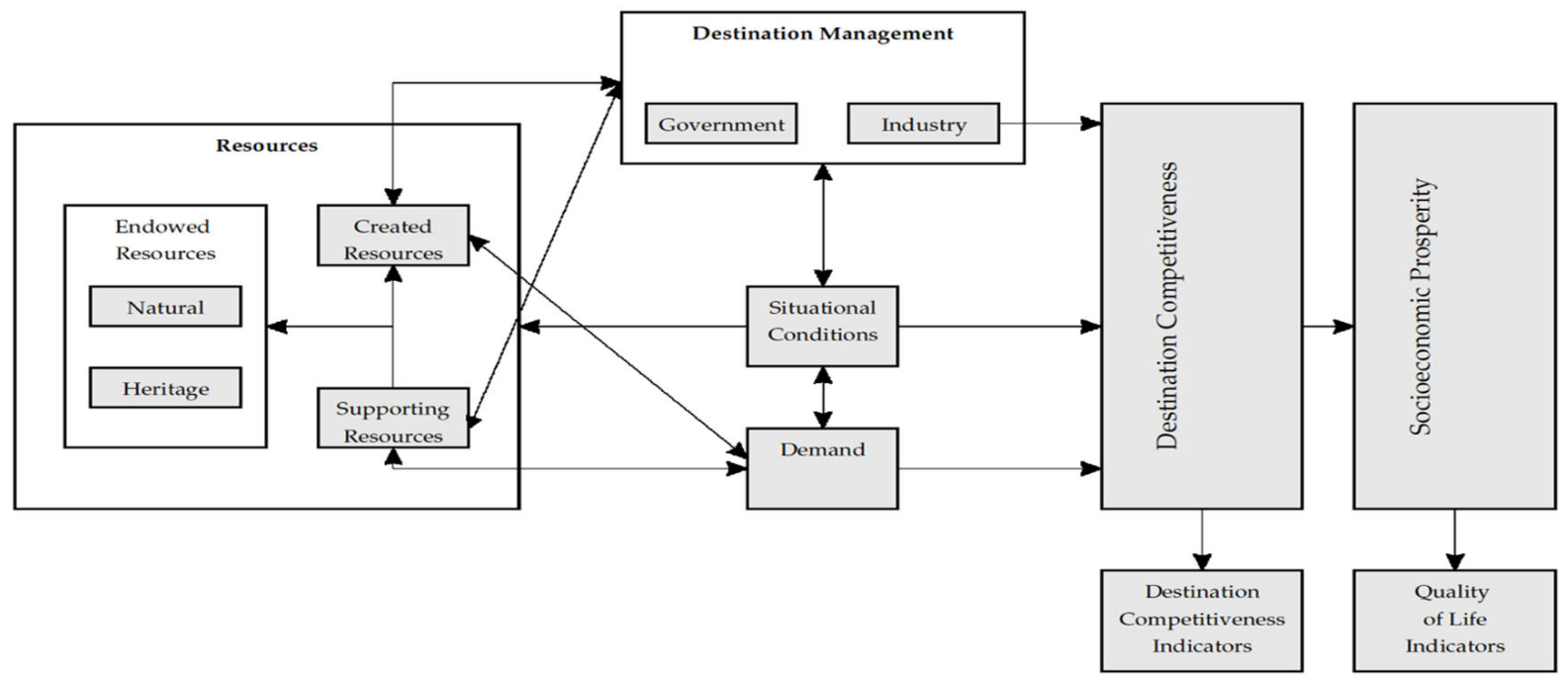

Source: Dwyer and Kim (2003).

Researchers have emphasized the difficulty of summarizing the competitiveness of tourist destinations into a small set of determinants and the existing models indicate that there exists an extensive list of these factors. However, according to Crouch (2011), it is unlikely that the numerous factors may have the same importance or influence in determining the competitiveness of tourist destinations. 


\section{METHODOLOGICAL ASPECTS}

The present investigation had a qualitative and descriptive nature. The qualitative approach emphasizes the oriented process and the experiential, providing means for developing an understanding of complex phenomena from the point of view of those that are living the phenomenon (MILES; HUBERMAN, 1994). The descriptive approach, in turn, displays characteristics of a given population or of a given phenomenon, seeking to describe them, classify them, and interpret them (LIMA, 2011).

The object of study was constituted by tourist destinations considered central along the Bioceanic Corridor between Campo Grande (state of Mato Grosso do Sul, Brazil) and Northern Chile (regions of Antofagasta and Tarapacá, Chile), namely, Campo Grande (BR), Porto Murtinho (BR), Mariscal Estigarribia (PY), San Salvador de Jujuy (AR), Salta (AR), San Pedro de Atacama $(\mathrm{CH})$, Antofagasta $(\mathrm{CH})$, and Iquique $(\mathrm{CH})$.

For each destination, we mapped specific information directly or indirectly related to tourism, for the competitive diagnosis. To this end, (1) interviews with local authorities ( 8 in total), (2) application of structured questionnaires to local specialists (8 in total), and (3) analysis of official documents and report on tourism and related activities were carried out. Data collection comprised the period from July 2019 to November 2020. The analytical exploration of the three information sources was fundamental for obtaining consistent results and consonant with reality.

For carrying out interviews, we chose the focused technique. The focused interview is preferable when a predominant theme or focus of interest orient the conversation and act as a parameter in the selection of interviewees. According to Flick (2009), the range of potentially relevant information provided by the interviewee is much more restricted than in other interviews and the interview script has a strong directive function toward the exclusion of unproductive topics.

The questionnaire was composed of 121 questions, including scales, multiple choice, and numeric answers. The instrument was adapted from Dwyer and Kim's (2003) model. This model gathers the main success factors and an appropriate set of indicators of competitiveness in tourist destinations. Thus, we believe that the indicators used here were sufficient to determine the competitive strengths and weaknesses of each destination.

\section{RESULTS}

Results obtained reveal nonconformity between the main cities in the corridor, such as Campo Grande, Salta, San Pedro de Atacama, and Iquique relative to all the elements analyzed, in relation to the other cities of the route, considering the itinerary starting in Campo Grande, toward the Chilean ports of Antofagasta and Iquique.

Campo Grande (BR), capital of the state of Mato Grosso do Sul, has a good level of attractiveness due to its conditions, resources, and attractions of value for the activity development. The city enjoys gastronomic corridors, a circuit of craft beers, a special typical dish (Sobá - a typical Japanese culture food), and a variety of bars and restaurants with varied dishes portraying the local culture. Among its attractions, it has historical buildings, streets, and squares comprising the local history, international racetrack, craft house, churches, malls, a large municipal market, and a museum of indigenous culture. There is a potential attractiveness still not optimized for consumption in tourism. Tourist information can be easily obtained on websites both institutional and commercial, along with tourist information points located in the airport and bus station. 
Because it is a "means locality", the city does not have air connections in direct flights to capitals of the Corridor countries, nor to its main cities. The internal transport can cater to tourist activity owing to the good availability of urban buses, taxis, and several transport applications. The hotel industry has approximately 7.5 thousand beds, which cater to the current flow but may be limited for investments in large events occurring simultaneously. As for supporting systems, it has a wide network of medical assistance, currency exchanges, public safety, and travel agencies. The cooperation for developing tourism in the capital is one of the strengths. The Municipal Tourism Council, a governance body that congregates the main actors both from the public sector and from the private enterprise, holds periodic meetings and is proactive in approaching themes relevant for the sector.

Porto Murtinho (BR) has resources and potential for tourism, but current conditions do not allow tours structured for marketing. The locality of approximately 17 thousand inhabitants has resources that can be used in favor of the development of interesting tourist products, such as exuberant nature, gastronomy with local characteristics and ingredients, and valuable history and culture associated with the development of the state and Brazil's Central-West region. The municipality has deficiencies in primordial areas for developing tourism, which can be limiting for a future increase of demand, such as reduced accommodation means and therefore low availability of beds, low number of restaurants, and little space for events. There is no urban transport system and the offer of transport applications is limited. The local community manifests a deep interest in the local tourism growth and demonstrates sympathy toward the idea of receiving a greater number of tourists.

According to Asato (2021), the architectonic and cultural condition that involves the Porto Murtinho population's self-esteem may facilitate cultural tourism development in the city.

Mariscal Estigarribia (PY) is located in a strategic region in the route that connects Brazil's border to Argentine's border. The city lies in the center of the north region known as Chaco Central, is approximately $250 \mathrm{~km}$ west of Porto Murtinho and $320 \mathrm{~km}$ of Pozo Hondo, and $70 \mathrm{~km}$ north of Loma Plata and the Mennonite community. This community, which originated from migrants from Germany and the Netherlands in the 18th century, maintains strong culture and religiosity features, which have influenced the way of life and the form of doing business. The Fernheim Cooperative has an important participation in industrializing and marketing local products, as well as innovations in water management.

Although this is, admittedly, a community of peculiar characteristics, which might generate interest in a potential demand, and though kind and hospitable, the Mennonites still have no disposition and openness for professional tourism. It is possible to highlight the strong presence of the autochthonous, indigenous culture, as well as a rich competence in producing crafts and artifacts representative of traditional peoples.

San Salvador de Jujuy (AR), in northwestern Argentine, is the capital of the province of Jujuy and has approximately 140 thousand inhabitants. This is one of the cities most influenced by indigenous peoples and by the Andean culture in Argentine. It has a strong Spanish colonization mark, represented in houses, buildings, and colonial architecture. The patrimony built has good attractiveness, of which the Cabildo city hall building that houses the Police Historical Museum, the Diocese of Jujuy, and the San Salvador Cathedral of Jujuy are examples. In addition, several museums, parks, natural attractions, squares, parishes, cultural centers, and beautiful natural landscape with good access from the center of the city, such as The Hill of Seven Colors in Purmamarca, are 
available. The main tourist information center is located in the municipal secretariat of tourism and counts with a large volume of information, maps, and guides specialized in local and regional tourism. The city's travel agencies offer packages and services for visitation of main sights in the surroundings, such as Humahuaca, Salinas Grandes, Iruya, and Termas de Reyes. Local airport and bus transfer, always available for downtown areas in disembarkation time, make access to the city easier. The city's service providers are well evaluated, especially bars and restaurants, but some tourist accommodation establishments have received negative evaluations. Better evaluated hotels are located in close cities, such as Tilcara and Vila Jardim de Reyes.

The city of Salta (AR) is about $100 \mathrm{~km}$ from San Salvador de Jujuy. The city has strong tourist appeal, a great variety of attractions, and good organization both public and private. The city has approximately 300 tourist accommodations (more than 12,300 beds), 162 travel agencies, 21 companies providing tourism-related services such as mountaineering, bicycle touring, and bird watching. The high season occurs in the month of July, with a good number of visitants, which extends until the month of December. In years prior to the pandemic in Salta, the city received one million tourists, more than $80 \%$ stemming from Argentine itself. The transport of passengers in the airline sector showed an increase of $141 \%$ in the number of passengers in six years, jumping from 691 thousand in 2012 to 1,122 in 2018, which indicates, among other things, the need for improvement in routes, access, and traffic because of this circumstantial increase in the circulation of people. We can also find the survey and availability of statistical data about tourism, related activities, and tourists' perception.

San Pedro de Atacama $(\mathrm{CH})$ is one of the most interesting destinations in the route to the Chilean coast. This is an exotic locality with quite peculiar characteristics, which attract national and international tourists, from the backpacker and adventurer, to the more demanding and traditional tourist. With fully formatted tourist products, several travel agencies organized with experienced local guides, and a range of attractions known worldwide, the destination has a high potential of attractiveness. Among the attractions, it is possible to know lakes, geysers, valleys, and museums. The gastronomy comprises Chilean, Atacama, and Altiplano dishes, and international food. The several daily less than two-hour flights from the capital Santiago to Calama or another close city such as La Serena or Antofagasta, facilitate the access. Land transport by bus also caters fully to the destination by several schedules available from the main cities, both from Chile and Argentine and Bolivia.

A number of blogs, institutional and commercial websites that bring information about what to visit, how to arrive, and other information necessary to the visitor, exist about the location. There are at least fourteen tour operators and at least 48 tourist accommodation establishments, between hotels, hostels, campsites, and rental houses. San Pedro de Atacama has received from tourists' positive observations, more than $80 \%$ of evaluations about the places to visit, gastronomy, and accommodations vary from "very good" to "excellent".

Known as "Pearl of the North", Antofagasta (CH) is located between the Atacama Desert and the Pacific Sea. The city has attractions centered in the historical period of saltpeter's economic cycle, set in and involved by the desert climate and landscape influence. In this scenario it is possible to visit the central region by city tour, the saltpeter of Chacabuco and the cemetery of Francisco Puelma, the ruins of Huanchaca, Raúl Zurita's geoglyph, and the Hand of The Desert. Moreover, there are tours aimed at Astronomia, in which visitors are invited to understand how ancient inhabitants of the Andes interpreted the universe, the Milky Way, and the nocturnal sky. 
Tourist information can be found on the official website of Chilean tourism ${ }^{4}$. However, because the website contains information about all destinations of the country, data about a single destination such as Antofagasta are restricted, and the interested person must seek other sources. The same does not occur in the information center in the center of the city, where it is possible to find vast digital and print content on local tourism.

Finally, the last city analyzed was Iquique, the capital of Tarapaca province and one of the most important cities in Northern Chile. In the urban center it is possible to visit museums and houses dating back to the 19th and 20th centuries, especially in Calle Baquedano, where the nitrate aristocracy built big houses with imported American-style raw material. In the central region one finds the Astoreca Palace, whose architecture is inspired in the Georgian style; the Municipal Theater of Iquique; the Cathedral of Iquique, and Plaza Prat. Among the museums, the Corbeta Esmeralda Museum, Municipal Museum of Iquique, and Museum of the Sea stand out. One of the city's most visited locations is the Zofri mall, Iquique's Free Trade Zone, where tourists can buy a wide variety of duty-free products. The Cavancha beach is one of the preferred locations for those who like surfing and walking by the sea. Another attraction is the Coberta Esmeralda, a replicate of the Chilean ship wrecked in the Pacific War in 1879. One of the most interesting places is the abandoned village of Humberstone and the Santa Laura saltpeter works. A Unesco heritage site, the small city housed workers from saltpeter refineries around 1880. In the location one finds a museum, houses, and well-preserved buildings; access via direct flight from Santiago and other important cities of the country such as Concepción, Rancagua, Santiago, Valparaíso, and La Serena, and by land by the Panamericana Road. Also by water, lquique has become an important destination for large cruise ships stopping or laying over, in international travels.

The accessibility measure makes this place the first world heritage site in the country to have an Accessible Tourist Circuit. At least two tourist information offices are available in person, one located close to the historical center and another in the Free Trade Zone's purchase region. In digital format, like in Antofagasta, the information available on official websites such as Sernatur is very limited. Consequently, the interested person must seek alternative websites and sources. Iquique has good overall infrastructure, with more than four thousand beds in hotels and other tourist accommodations, travel agencies, currency exchanges, and information points.

Cross-border tourism is also in the focus of municipal management. The idea is to broaden the attractiveness of tourists who come from Bolivia, especially Uyuni and Oruro. Considering Argentine, Iquique receives many holiday and weekend visitors stemming from Jujuy and Salta, even if not bordering the Tarapacá province. Iquique's tourism has been governed by way of council since 2019, which is called Municipal Governance of Tourism, includes among its members the Sernatur, two state universities, two chambers of commerce (tourism and retail), hotel associations, restaurants and travel agencies, Free Trade Zone, among others. The council operates actively and has the active participation of private enterprise, meets every 15 days, Iquique's city hall making the chairmanship. The city lives a period of positive expectations in an environment favorable for businesses. Resources have been approved for implementing the project "Economic Reactivation of Iquique's Port and of the Logistics Chain". We did not identify official data regarding the tourists' perception about the services provided. Online comments left by users at Tripadvisor, the world's largest travel website, show a good

\footnotetext{
${ }^{4}$ https://www.visitchile.com
} 
satisfaction index as for service providers with $80 \%$ of them standing between "very good" and "excellent".

In investigating the main cities that the Brazil-Paraguay-Argentine-Chile Bioceanic Route will cross, our purpose is to trace a parallel between these destinations according to the following analysis criteria: Attractiveness, Tourist Information, Transport, General Infrastructure, Quality of Services, Accessibility, Hospitality, Trade Relations, Destination Management, Conditional Situations, and Tourists' Perception.

In the business environment a resource is a general term used to name assets, capacities and processes that allow conceiving and implementing strategies efficiently and effectively. This idea has been transposed to analyze the competitiveness of tourist destinations, to compare them and identify those that are in better conditions of offering unique products with high value for an attractive price. In this sense, by considering items such as attractiveness, tourist information, hospitality, and all the others, we examine such items as valuable resources to produce greater results in the tourist destination. The idea is that, with a solid base, the location may obtain positive results relative to other competitors.

Figure 2 - Radar Analysis of Axis Destinations

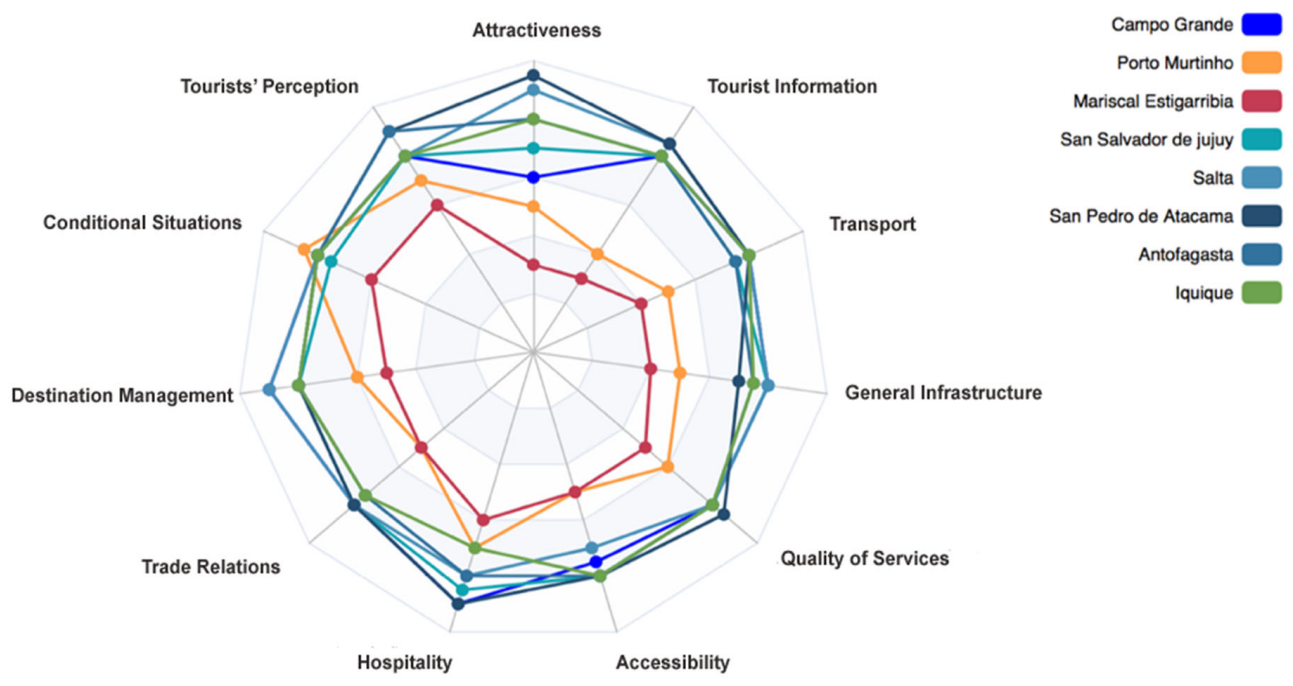

Source: Research data.

We now examine each one of the focal variables and extract from them their capacity of influencing competitiveness in the Corridor's tourist destinations, beginning by the tourist information, considered essential to establish a harmonious relationship with potential consumers, interested tourists, specialized media, and organizations in the sector.

The tourist information comprises not only efficient communication concerning what the location holds but might also evolve to establish an intentional relationship that leads the interested person to consume and try out tourism products. That said, this variable is only fully effective when there are tourist products consolidated and available for consumption, so-called off-the-shelf products, which can be proffered by travel agencies for a given price.

In the first scenario, the Campo Grande, Jujuy, Salta, San Pedro, Antofagasta, and Iquique destinations assume a prominent position, with information available to fully cater to tourism. 
On the other hand, potential destinations such as Porto Murtinho and Mariscal Estigarribia, amid an increasing number of transients and having a potential tourist resource, should consider improving communication instruments so as to establish a culture of relationship and closeness with visitors.

The variable transport involves both the system of access to the destination and the internal transport system catering to travels between locations of interest. The presence of a good system of access to the destination helps in attracting visitants from several emitting regions, as well as in the municipal management's strategic choices relative to the desired tourist profile.

Thinking internal transport in a strategic way might help value exponentially local tourism. Campo Grande stands out for its privileged geographic position, in central-southern South America, and is of easy access from the main tourist-emitting hubs such as São Paulo or Buenos Aires. However, it does not have direct flights connected with the other Bioceanic Corridor's axis destinations, such as Salta or Antofagasta. This is a condition that affects the other destinations in our assessment since the connections are established at first with state and national capitals. Transport to other cities demands a higher waiting time between one flight and another.

In addition to Campo Grande, Salta and San Pedro de Atacama stand out. Salta stands in a privileged position because it caters very well to emitting regions showing clear growth in the number of passengers and landings. San Pedro is the example of a region whose attractiveness potential surpasses access difficulties, especially for those that arrive after travel to the Andes Mountains, attracting not only adventurers but a wide audience. In all destinations analyzed, internal transport is not structured so as to improve the tourist's experience. Attention should be given to potential destinations where there is no transport system for the local population or it is quite limited. In this situation are Porto Murtinho and Mariscal Estigarribia. Some negative aspects, as indicated by tourists, were identified in the Antofagasta region. Iquique has a privileged position with the possibility of seeking foreign tourists and establishing commercial partnerships for building routes integrated with countries and destinations in neighboring countries.

General infrastructure recognizes the infrastructure and urban equipment directly and indirectly related to tourism. Among them we can cite tourist roads, railroads, bridges, highways, tunnels and overpasses, river, lake, and sea banks; basic sanitation (water, sanitary, and solid waste treatment); bus stations, railheads, air transport links, fluvial, lacustrine, and marine terminals; public constructions aimed at tourism-inducing activities such as cultural centers, museums, houses of memory, convention centers, tourist support centers, theaters, craft products trade centers, and public overlooks; monuments, and historical sets ${ }^{5}$.

Overall, the destinations show good infrastructure conditions, but some require improvement in the condition of equipment directly related to tourism. In Porto Murtinho, the river bank region demands constant maintenance against erosion and does not have a structure built for contemplation of nature or even departure and landing of passengers in a safe way and protected from the weather. In its turn, Mariscal Estigarribia has limitations in asphalt pavement infrastructure and general infrastructure associated with the tourists' reception. In Antofagasta and Iquique, the infrastructure is adequate for catering to tourism. However, something occurs that is not uncommon to the Corridor's destinations, the existing infrastructure blends with that

\footnotetext{
${ }^{5}$ Prodetur + Turismo. Available at http://www.prodetur.turismo.gov.br/index.php?option=comcontent \&view=article\&id=132:infraestrutura-turistica\& catid=16\&Itemid=309
} 
aimed at catering to the resident population, few structures being directed specifically at the visitor.

As to quality of services, we note that the Bioceanic Corridor's destinations have been well evaluated by visitors. Once the evaluation regarding the quality of a service or product is naturally subjective, derived from consumption profile and individual experiences, we obtained evaluations from the main online evaluation mechanisms in which the tourists leave their impressions, or by means of research directed by the municipal management.

Salta, San Pedro de Atacama, and Antofagasta have received the best evaluations. The tourists' perception about Salta highlights that the best in the city is related to the landscape, to nature, to the climate, to hospitality, and the peacefulness. The factors considered that can still be improved are traffic, routes and paths, and prices. However, Antofagasta's case draws attention for amid positive assessments there are several observations as to the specialization of services, in that many providers are focused on catering to clients with demands and purposes different from leisure, such as those found in the mining industry. In Jujuy, the National Secretariat of Tourism awarded the Tourist Information Cabinet for the implementation of the ISO 14785 International Norms and the province has promoted meetings with private enterprise to discuss the improvement of the quality of services offered by tourism providers. In Iquique there are no records of satisfaction or assessment of tourism-associated services. Campo Grande lacks specific research of the official tourism body's responsibility in the municipality.

Concerning accessibility, the means available to access the destination, as well as travel time and (inter)modal connections along the route, can contribute, extremely, to attracting visitors, especially in a scenario with scarcity of leisure or rest time. In a post-pandemic scenario, putting the family in a car and traveling some kilometers can be an alternative for a public longing for traveling and including their path in the list of good experiences beyond the final destination. There may be significant increase of interest and demand for organized tourist routes and circuits, in good conditions to absorb the passage of tourists comfortably and safely.

Hospitality refers to acts and behaviors associated with well receiving tourists or visitors in a given locality. It is strongly related to the competitiveness of tourist destinations because it is one of the most expressive ways of demonstrating, by means of attitudes and behaviors, how the tourist is desired and dear in being in the locality.

Among the Bioceanic Corridor destinations, Campo Grande assumes a prominent position relative to hospitality. In research carried out by the Ministry of Tourism, the state of Mato Grosso do Sul was pointed out as the most hospitable of Brazil. With $99.6 \%$ votes, it surpassed four large states as Rio de Janeiro, São Paulo, Bahia, and Pernambuco. This result is especially due to the Campo Grande capital and the Bonito ecotourism destination.

In Porto Murtinho available data indicate that the population has a good disposition for tourism. However, mechanisms for coordinate and systematic information search and data survey by official bodies, are needed. The same goes for Mariscal Estigarribia, where the population seems to be receptive and welcoming, but there are no empirical studies confirming this reality. The province of Salta has good numbers on hospitality, as indicated by tourists in the list of the "best things in Salta". However, the survey of specific data in the city of Salta would enrich strategic decision-making and the capital's market positioning. In the case of San Salvador de Jujuy, the community has availability and sympathy toward tourism. This is reflected in assessments made by tourists on specialized websites. A similar situation occurs 
both in Antofagasta and in Iquique, where there are supporting statistics about hospitality, but the good reception and cordiality of residents is reflected in assessments left by tourists on the web. As for San Pedro, hospitality is characterized by the professional behavior and cordiality of a town used to the flow of tourists.

The trade relations variable concerns the establishment of cooperation agreements and commercial incentives for promoting tourism, stimulating and facilitating the flow of people between tourist regions, as well as the carrying out of specific promotion and publicity actions with the purpose of attracting visitors of an issuer market.

In the Bioceanic Corridor context, the stimulus to the transit of passengers and tourists invariably goes through trade diplomacy, including multilateral (WTO), regional, and bilateral mechanisms. In this regard, Brazil has a long-lived diplomatic and commercial relationship with the Corridor's neighboring countries.

The similarity between the destinations analyzed is the focus on national issuer markets with easy air connection. The Bioceanic Corridor opens an array of opportunities to integrate connections between tourist destinations consolidated or with high development potential, for example, Campo Grande and Salta, and Jujuy and Iquique. Destinations incipient in tourism, such as Porto Murtinho and Mariscal Estigarribia, might invest in attracting the regional and cross-border tourist, that who prefers traveling in their automobile with the family, enjoying the landscape and the travel rhythm itself, closer to the so-called slow tourism ${ }^{6}$.

Initially, the focus of trade relations must be to facilitate the flow between the four countries, which means creating mechanisms to integrate itineraries, the increase of tourists' interest in enjoying attractions between countries, consumption of well-established tourist products and others, still consolidating, along with the stimulus to the trade of goods, asset and durable products, this being an important enabler of new air routes and motivator of the air transport of passengers.

Destination management is one of the determining factors for the good use of resources available in the destination. A good municipal management, in the case of tourist destinations, marked by the broad participation of civil society, representatives of associations and trade associations already consolidated such as of the hotel sector, restaurants, travel agencies and tourist attractions, of the municipal and state government, contributes greatly for the destination to construct, in a consistent way, a collective and democratic understanding about tourism.

Campo Grande is organized in the form of a council. The Municipal Tourism Council (COMTUR) gathers the main people interested in developing local tourism. The fact that this is an active council, with periodic meetings, participative and broadly representative, that indeed helps meet the needs and demands of the sector in Campo Grande, is of greater relevance. Porto Murtinho has a Comtur established, though not active and little representative. The involvement of businessmen, associations, and other interested persons has been one of the focuses of work of the municipal secretariat of tourism.

In Mariscal Estigarribia there are no records of organized tourism governance activities. In Salta, the joint work of the main entities connected to tourism stands out, the active Municipal Tourism Committee, decision-making and municipal bodies, and the private sector. The same

\footnotetext{
${ }^{6}$ Slow tourism is a trend in ways of traveling and travel, which has a slower rhythm, in which the tourist enjoys the landscape, values sustainability and the relationship with people, cultures, and attractions along the way.
} 
occurs in Jujuy, with an active council, representative of the interests of society and tourist trade; in San Pedro de Atacama, with the Community Tourism Committee; in Antofagasta, with the Board of Directors for Tourism and Businesses in the Antofagasta Region, and in Iquique, with the so-called Municipal Tourism Governance.

The conditional situations variable is related to the existence of an opportunity environment for the tourist destination generally associated with the improvement of economic and/or sociocultural conditions in the local or regional context. At times, a whole set of environmental factors make opportunities emerge for human capital development, job opportunities and family income improvement, investments in education, culture, leisure and entertainment, and emergence of new businesses in areas directly and indirectly linked to tourism. In the Bioceanic Corridor context there is a noticeable environment of trust that the materialization of constructions and opening of the logistic path will bring prosperity opportunity to the destinations along the route.

We infer, too, that the optimistic environment of opportunities is present in all municipalities along the Corridor route, from Campo Grande to Chilean ports. This means that each community may draw on the road flow increase and take advantage of it as per convenience, creativity, and need, with higher or lower investment. The opportunities go from the sales volume increase of the roadside vendor who sells his products stemming from family farming or crafts, to the arrival and implementation of large corporations, logistic companies, and industries.

The tourists'perception establishes a basic parameter so that the local tourism management can focus efforts and investments. This is an indicator that portrays the situation of ongoing tourism and developing activities and, for this reason, can be considered a good thermometer to assess how much the destination has conditions to compete with others, in the attentive perspective of those most concerned and consumers: the tourists. Of the municipalities evaluated, Mariscal Estigarribia is the only one that still does not have tourism activity or monitoring of visitors passing through the municipality.

Attractiveness is one of the essential criteria to identify a destination's competitiveness level. It concerns the destination's capacity to awaken genuine interest in being in the location or knowing its attractions. It is totally related to the level of offer of attractions and tourist products. Some characteristics are fundamental to strengthen attractiveness, among them the organization around tourist products, the quality and diversity of attractions, their singularity and rarity relative to the others available in competing destinations, and the value of the experience and of that which is lived, which is unique and memorable.

Campo Grande can be classified as a regional and national attractiveness destination with small international market incidence (only $4.1 \%$ of arrivals are of foreigners). Porto Murtinho has good potential for developing tourist products and services in segments outside the fishing circuit. Together, history, culture, crafts, gastronomy, and natural environment may form very attractive products, of great novelty in the state of Mato Grosso do Sul.

Mariscal Estigarribia has its attractiveness potential associated with cultural traditions, music, and dance, but the low engagement with the organization and management of these resources for tourist purposes compromises the general attractiveness potential.

San Salvador de Jujuy is located at the foot of the Andes, in the Central Cordillera portion, and is one of the last support points before the crossing of the mountains. It shows good conditions for developing tourism in the city, with good basic and tourist infrastructure. Greater exploitation potential occurs outside the urban limits, as in Salinas Grandes and Quebrada de Humahuaca. 
Salta, like San Salvador de Jujuy, is located at the foot of the Cordillera. For this reason, it enjoys an incredible mountainous landscape that receives and enchants visitors. Beyond the natural resource, it has a good variety of cultural, gastronomic, and religious attractions, circuits and tours. Some of them draw attention for the attractiveness power and help distinguish Salta from other destinations, such as the Train to the Clouds and the Cable Car. Salta has good conditions of organization and management of tourism; it even offers an up-to-date calendar of local events, which is available on the webpage of the municipal secretariat of tourism. These factors, together with the good perception and image of the city, make Salta stand out in attractiveness in the Bioceanic Corridor.

San Pedro de Atacama is an eminently tourist locality with strong tourist attractiveness. Its vocation is entirely aimed at meeting the tourist demand in several types of publics, from campers and adventurers to more traditional and demanding ones. The availability of tourist equipment, such as hotels, restaurants, and travel agencies impresses not only for the quantity, but for the variety and quality, so much so that many companies have received the highest marks from the consuming public. It has managed to develop a unique and strong identity amid the scarcity of resources in the Atacama desert. The good synergy between all local resources, be they natural, artificial, or human, makes San Pedro one of South America's main tourist destinations. Thus, the city holds a high degree of attractiveness and competitiveness among the Bioceanic Corridor destinations.

Antofagasta is a locality of great tourism potential but lacks improvement to broaden the attractiveness power. Although Antofagasta has varied tourist circuits and paths, there is a deficit in infrastructure and equipment to cater to the tourist. Especially by reason of the strength of mining activity, responsible for $49 \%$ of Chilean Gross Domestic Product (GDP) and $56.3 \%$ of the Antofagasta region GDP, to which the service providers, among them restaurants, hotels, and transport companies turn their energy and attention focus before the tourism clients.

Iquique assumes a prominent position relative to attractiveness. The city shows historic, cultural, and natural attractions with unique characteristics and of great value not only in the region, but which can be explored in the economic development context of Latin America. In addition to its historical vocation, it shows good attractiveness by means of the beaches and the Free Trade Zone, which attract tourists from close regions and from neighboring countries.

\section{FINAL CONSIDERATIONS}

The central aim of this study was to identify the level of competitiveness of the Bioceanic Corridor's axis destinations. Therefore, we sought to qualify the main attributes associated with the competitiveness of a destination, highlighting the strengths and limiting aspects in each one of them. We stress that competitiveness is a multidimensional concept involving complex variables in its nature and of difficult measurement.

We understand that the results here achieved are incipient and should be confronted with complementary information. Thus, we intend to open a field of discussion that may contribute, in Bioceanic Corridor context, to the evolution of qualified and organized tourism that may, in addition to satisfy tourists and visitors, generate jobs, increase family income, and improve the inhabitants' quality of life in each destination or stopping point along the Campo GrandeNorthern Chile route.

INTERAÇÕES, Campo Grande, MS, v. 22, n. 4, p. 1287-1301, out./dez. 2021. 


\section{REFERENCES}

ASATO, T. A. A Rota Bioceânica como campo de possibilidades para o desenvolvimento da atividade turística. 2021. Tese (Doutorado em Desenvolvimento Local) - Universidade Católica Dom Bosco, Campo Grande, MS, 2021.

CROES, R. Measuring and explaining competitiveness in the context of small island destinations. Journal of Travel Research, [s.I.], v. 50, n. 4, p. 431-42, 2011.

$\mathrm{CROUCH}, \mathrm{G}$. Destination competitiveness: an analysis of determinant attributes. Journal of Travel Research, [s.l.], v. 50, n. 1, p. 27-45, 2011.

CROUCH, G.; RITCHIE, J. Tourism, competitiveness, and societal prosperity. Journal of Business Research, [s.I.], v. 44, n. 3, p. 137-152, 1999.

DWYER, L.; KIM, C. Destination competitiveness: determinants and indicators. Current Issues in Tourism, [s.I.], v. 6, n. 5, p. 369-414, 2003.

DWYER, L.; CVELBAR, L.; EDWARDS, D.; MIHALIC, T. Fashioning a destination tourism future: the case of Slovenia. Tourism Management, [s.I.], v. 33, n. 2, p. 305-16, 2012.

DWYER, L.; MELLOR, R.; LIVAIC, Z.; EDWARDS, D.; KIM, C. Atributes of destination competitiveness: a factor analysis. Tourism Analysis, [s.I.], v. 9, n. 1-2, p. 91-101, 2004.

ENRIGHT, M.; NEWTON, J. Tourism destination competitiveness: a quantitative approach. Tourism Management, [s.I.], v. 25, n. 6, p. 777-88, 2004.

FLICK, U. Introdução à pesquisa qualitativa. Porto Alegre: Artmed, 2009.

HEATH, E. Towards a model to enhance Africa's sustainable tourism competitiveness. Journal of Public Administration, [s.I.], v. 37, n. 3.1, p. 327-53, 2003.

LIMA, L. A representação das múltiplas dimensões paradigmáticas no estudo da administração: um ensaio sobre os limites contidos nas defesas paradigmáticas excludentes. Revista de Administração Contemporânea, Curitiba, v. 15, n. 2, p. 198-208, 2011.

MAZANEC, J.; WOBER, K.; ZINS, A. Tourism destination competitiveness: from definition to explanation? Journal of Travel Research, [s.I.], v. 46, n. 1, p. 86-95, 2007.

MILES, M.; HUBERMAN, A. Qualitative data analysis. Thousand Oaks, CA: Sage, 1994.

MIKI, A.; GÂNDARA, J.; MUÑOZ, D. O estado atual de pesquisas sobre competitividade turística no Brasil. Caderno Virtual de Turismo, Rio de Janeiro, v. 12, n. 2, p. 212-23, 2012.

RITCHIE, J; CROUCH, G. Competitiveness in international tourism: a framework for understanding and analysis. In: CONGRESS OF THE ASSOCIATION INTERNATIONALE D'EXPERTS SCIENTIFIQUE DU TOURISME, 43., 17-23/out. 1993, San Carlos de Bariloche. Anais [...]. San Carlos de Bariloche: AIEST, 1993.

RITCHIE, J.; CROUCH, G. The competitive destination: a sustainability perspective. Tourism Management, 21: 1-7, 2000.

RITCHIE, J.; CROUCH, G. The competitive destination: a sustainable tourism perspective. Wallingford: CABI Publishing 2003. 
RODRÍGUEZ-DÍAZ, M.; ESPINO-RODRÍGUEZ, T. A model of strategic evaluation of a tourism destination based on internal and relational capabilities. Journal of Travel Research, [s.I.], v. 46, n. 4, p. 368-80, 2008.

ZHANG, H.; CHAO-LIN, G.; LU-WEN, G.; ZHANG, Y. The evaluation of tourism destination competitiveness by TOPSIS \& information entropy: a case in the Yangtze River Delta of China. Tourism Management, v. 32, n. 2, p. 443-51, 2011.

\section{About the authors:}

Erick Pusch Wilke: Doctorate in Business at the Nove de Julho University (UNINOVE). Master's Degree in Culture and Tourism at the State University of Santa Cruz (UESC). Graduated in Tourism at the State University of Ponta Grossa (UEPG). Professor at the Federal University of Mato Grosso do Sul (UFMS), while working mainly at the following areas: Organizational Strategies; Hotelier Management and Administration; Marketing and Tourism. E-mail: erick.wilke@ufms.br, Orcid: https://orcid.org/0000-0001-9443-1255

Débora Fittipaldi Gonçalves: PhD Student of the Post-Graduation Strictu Sensu Program in Local Development at the Dom Bosco Catholic University (UCDB). Doctorate with partial completion at the University of Barcelona (UB) through the Program of Management of Culture and Heritage, with a CAPES' scholarship. Doctorate and Masters in Regional Development at the Regional University of Blumenau (FURB-SC). Specialist in Methodology of Higher Education at the University Centre of the Grande Dourados Region (UNIGRAN). Graduated in Tourism at UCDB and Pedagogy at UNIGRAN. Currently, is the coordinator and a professor of the Tourism Major department at the State University of Mato Grosso do Sul (UEMS), in Campo Grande. E-mail: defittipaldi@uems.br, Orcid: https://orcid.org/0000-0002-4664-8174

Thiago Andrade Asato: Doctorate and Master's degree in Local Development at the Dom Bosco Catholic University (UCDB). Executive MBA in Economic and Strategic Management at Ampere College (FAMPER). Graduated in Tourism at UCDB. Currently is a professor of the Tourism department at the State University of Mato Grosso do Sul (UEMS), and in the Business department and Post-Graduate program in Management at Novoeste College. E-mail: thiago_andrade_asato@hotmail.com, Orcid: http://orcid.org/0000-0001-8865-1518 
